\title{
The influence of riboflavin deficiency on absorption and liver storage of iron in the growing rat
}

\author{
By DELANA A. ADELEKAN* AND DAVID I. THURNHAM $\dagger$ \\ Department of Human Nutrition, London School of Hygiene and Tropical Medicine, \\ Keppel Street, London WCIE $7 H T$
}

(Received 25 November 1985 - Accepted 22 January 1986)

1. Iron absorption was measured in weanling riboflavin-deficient (RD) rats or weight-matched (WM) controls fed on appropriate diets for 7 weeks. Concentrations of radio- $\mathrm{Fe}\left({ }^{59} \mathrm{Fe}\right)$ in plasma were monitored every $30 \mathrm{~min}$ for $4 \mathrm{~h}$ following intragastric administration.

2. Total $\mathrm{Fe}$ absorption in RD rats was significantly lower than that in WM controls, and the tissues of the stomach and small intestine of RD rats retained significantly $(P<0.001)$ more ${ }^{59} \mathrm{Fe}$ by comparison with WM groups.

3. In a separate experiment, ferritin-Fe concentrations were measured in the livers of four groups of rats (ad lib. (C), pair-fed (PF) and WM controls and RD) at day 0 , and subsequently at days 14, 21, 28, 35 and 49.

4. Liver ferritin-Fe concentration was significantly lower $(P<0.05)$ in RD rats than in all other controls after 3 weeks on the respective diets and remained lower for the remainder of the experiment.

Riboflavin deficiency in animals and man has been associated with several disturbances of iron metabolism including a reduction in haemoglobin concentration, bone marrow hypoplasia and variable degrees of anaemia (Mookerjea \& Hawkins, 1960; Lane et al. 1964; Alfrey \& Lane, 1970).

The liver is the main site of $\mathrm{Fe}$ storage and approximately $60 \%$ of total non-haem-Fe in normal rats is present as ferritin (Van Wyke et al. 1971) and most of the remainder as haemosiderin (Linder et al. 1973). Zaman \& Verwilghen (1977) and Sirivech et al. (1977) reported lower concentrations of non-haem-Fe in the livers of riboflavin-deficient rats. Sirivech et al. (1977) suggested that the lower concentration of ferritin-Fe in liver of riboflavin-deficient rats may be the consequence of decreased activity of the flavin-dependent enzyme, NADH-FMN oxidoreductase ( $E C$ 1.6.8.1 ). This enzyme is responsible for the mobilization of $\mathrm{Fe}$ from ferritin in tissues, and Sirivech $\mathrm{et}$ al. (1977) reported that the activity of this enzyme in duodenum, kidneys and liver of riboflavin-deficient rats was significantly lower than that in control rats. This enzyme does not influence the uptake of Fe into the liver, however, since Zaman \& Verwilghen (1977) showed that the incorporation of Fe into liver ferritin in response to intravenously administered radio- $\mathrm{Fe}\left({ }^{59} \mathrm{Fe}\right)$ was similar in both riboflavin-deficient and control rats. The lower concentration of $\mathrm{Fe}$ in the liver of riboflavin-deficient rats would appear, therefore, to be due to impaired absorption of food Fe.

The present study was designed to study $\mathrm{Fe}$ absorption in riboflavin-deficient rats and to investigate longitudinally the storage of Fe during riboflavin deficiency.

MATERIALS AND METHODS

All chemicals used were obtained from British Drug Houses (BDH) Ltd, Poole, Dorset, unless otherwise stated.

Present addresses: * Department of Paediatrics and Child Health, Faculty of Health Sciences, University of Ife, Ile-Ife, Nigeria. † Clinical Investigation Unit, Dudley Road Hospital, Dudley Road, Birmingham B18 7QH.

$\ddagger$ Number allocated to a similar enzyme isolated from microbiological sources (Shiao-Chun et al. 1979). 


\section{Experimental animals}

Male, weanling, Wister albino rats, weighing 50-60 g, were used in the two experiments. Rats were housed individually in white plastic, wire-bottomed cages in a well-ventilated room at a temperature of $26-28^{\circ}$. Rats were allocated to dietary groups and fed as described in Table 1 for a period of 7 weeks. Table 2 shows the composition of the diets used.

\section{Expt 1}

Two groups of six rats each (riboflavin-deficient (RD) and weight-matched (WM) controls) were used in the study. After the feeding period, rats were fasted for about $18 \mathrm{~h}$ but water was provided ad lib. ${ }^{59} \mathrm{FeCl}_{3}$ (specific activity $13 \mathrm{mCi} / \mathrm{mg} \mathrm{Fe}$; Amersham International plc, Amersham, Bucks), $100 \mu \mathrm{Ci} / \mathrm{kg}$ body-weight, was administered into the stomach of each rat through a catheter (no. 4 gauge; Arnold's Veterinary Products Ltd, Reading), under light diethyl-ether anaesthesia. The isotope was diluted in $0.154 \mathrm{M}$-sodium chloride solution containing $340 \mu \mathrm{M}$-trisodium citrate. Food pots were replaced in cages $3 \mathrm{~h}$ after the intragastric administration of radio-Fe.

Blood $(50 \mu \mathrm{l})$ was drawn from the tail vein of each rat into capillary tubes at $30 \mathrm{~min}$ intervals for $4 \mathrm{~h}$ following the intragastric administration of ${ }^{59} \mathrm{Fe}$. Capillary tubes were then centrifuged in a Hawksley microcentrifuge; $20 \mu \mathrm{l}$ plasma were drawn into Unibore break-off capillary tubes (Harshaw Chemicals Ltd, Daventry, Northants) and the radioactivity counted in a gamma counter. The fraction of radioactivity removed from the plasma by different tissues of the body at each time-period was calculated from the formula of Bothwell et al. (1955).

Fraction of Fe removed $(F)$ during a $30-\min$ period $=0.693 \times 30 / t_{0.5}$,

where $t_{0.5}$ is the half-life(min) of ${ }^{59} \mathrm{Fe}$ in plasma following intravenous (iv) administration of ${ }^{59} \mathrm{Fe}, 0.693$ is the natural logarithm of 2 and $F$ is 0.2599 and 0.3465 for RD and WM rats respectively based on plasma ${ }^{50} \mathrm{Fe}$ half-lives of 80 and $60 \mathrm{~min}$ (see Fig. 3, p. 175).

The loss in radioactivity during each $30 \mathrm{~min}$ period $(X)$ was calculated as the average activity over the period $\times F$.

The estimated true number of counts of ${ }^{59} \mathrm{Fe}$ absorbed at the end of each time-interval, assuming no removal from plasma, $=(X+Y+Z)$, where $X$ is the calculated losses in radioactivity during each $30 \mathrm{~min}$ period, $Y$ is the rise in counts over each $30 \mathrm{~min}$ period (where a fall occurred, $Y=0$ ), $Z$ is estimated counts at the start of the same $30 \mathrm{~min}$ period. The estimated true counts were then plotted linearly $v$. time.

Rats were killed at the end of $4 \mathrm{~h}$ by cardiac exsanguination under light diethyl-ether anaesthesia. The stomach and the entire length of small intestine of each rat were dissected out, rinsed with distilled water and digested separately in $3 \mathrm{ml} 6 \mathrm{M}$-nitric acid. Portions ( $1 \mathrm{ml}$ ) were counted for radioactivity in a well-type gamma counter. No determination of unabsorbed $\mathrm{Fe}$ in faeces was made because rats were killed at the end of $4 \mathrm{~h}$.

Plasma Fe disappearance rate (plasma $t_{0.5}$ ) was determined in three other groups of rats (ad lib. control (C), RD and WM) fed for a period of 7 weeks. After an overnight fast $100 \mu \mathrm{Ci}$ ${ }^{59} \mathrm{FeCl}_{3}$ (specific activity $13 \mathrm{mCi} / \mathrm{mg} \mathrm{Fe}$; Amersham International plc)/ $\mathrm{kg}$ body-weight was injected through the tail vein. Whole blood $(50 \mu \mathrm{l})$ was drawn from each rat into capillary tubes at intervals of 20,40,80 and $160 \mathrm{~min}$ after the administration of radio-Fe and handled as described previously. The number of counts of radioactivity in plasma at each interval was plotted (semi-log) to give a straight line which was then extrapolated to the $Y$ axis to give total counts at time zero $\left(t_{0}\right)$. Plasma volume was estimated from the packed cell volume and assuming a blood volume of $60 \mathrm{ml} / \mathrm{kg}$ body-weight (Jamdar et al. 1968). The plasma $\mathrm{Fe}$ disappearance rate (plasma $t_{0 \cdot 5}$ ) was then determined as the time (min) taken for ${ }^{59} \mathrm{Fe}$ in plasma at $t_{0}$ to be reduced by half. 
Table 1. Dietary regimen in experimental groups of rats

\begin{tabular}{lll}
\hline Dietary group & & Dietary regimen \\
\hline $\begin{array}{l}\text { Riboflavin-deficient (RD) group } \\
\text { Control groups } \\
\text { Ad lib. }\end{array}$ & Experimental RD diet (Table 2) & Fed ad lib. \\
Pair-fed & $\begin{array}{c}\text { Experimental diet }+22 \mathrm{mg} \\
\text { riboflavin } / \mathrm{kg} \\
\text { Experimental diet }+22 \mathrm{mg} \\
\text { riboflavin } / \mathrm{kg} \\
\text { Experimental diet }+22 \mathrm{mg} \\
\text { riboflavin } / \mathrm{kg}\end{array}$ & $\begin{array}{c}\text { Fed ad lib. } \\
24 \mathrm{~h} \text { feeds restricted to previous } \\
24 \mathrm{~h} \text { intake of RD group } \\
\text { Body-weight restricted to match } \\
\text { that of RD group by adjusting } \\
\text { feed intake accordingly }\end{array}$ \\
\hline
\end{tabular}

Table 2. Major constituents of the diet $^{*}(\mathrm{~g} / \mathrm{kg}$ diet $)$

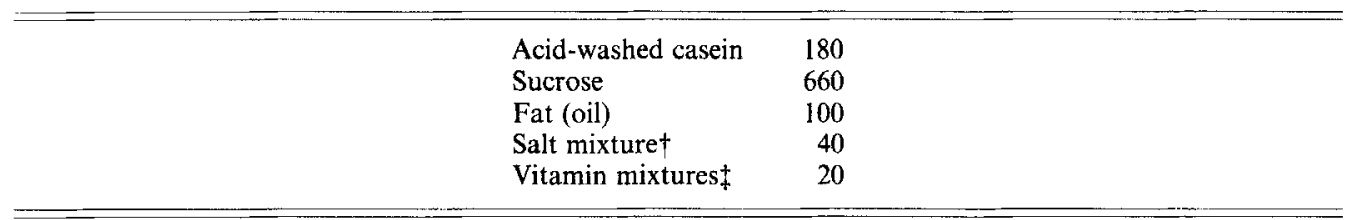

* Based on the formula of Hoppel \& Tandler (1975) with slight modifications.

$\dagger$ The salt mixture was composed of the following salts $(\mathrm{g}): \mathrm{Al}_{2}\left(\mathrm{SO}_{4}\right)_{3} \cdot \mathrm{K}_{2} \mathrm{SO}_{4}, 24 \mathrm{H}_{2} \mathrm{O} 0 \cdot 21, \mathrm{CaCO}_{3} 309 \cdot 83$, $\mathrm{CaHPO}_{4} .2 \mathrm{H}_{2} \mathrm{O} 98 \cdot 12, \mathrm{CoCl}_{2} .6 \mathrm{H}_{2} \mathrm{O} 0 \cdot 26, \mathrm{CuSO}_{4} .5 \mathrm{H}_{2} \mathrm{O} 0 \cdot 21, \mathrm{FeC}_{6} \mathrm{H}_{5} \mathrm{O}_{7} .5 \mathrm{H}_{2} \mathrm{O}$ (omitted from the mixture used in the iron-deficient diet) $6 \cdot 0, \mathrm{MgSO}_{4} . \mathrm{H}_{2} \mathrm{O} 51 \cdot 13, \mathrm{MnSO}_{4} . \mathrm{H}_{2} \mathrm{O} 4 \cdot 13, \mathrm{KI} 0 \cdot 83, \mathrm{~K}_{2} \mathrm{HPO}_{4} \cdot 3 \mathrm{H}_{2} \mathrm{O} 333 \cdot 09, \mathrm{NaCl} 173 \cdot 0$, $\mathrm{NaF} 0 \cdot 26, \mathrm{Na}_{2} \mathrm{~B}_{4} \mathrm{O}_{7} .10 \mathrm{H}_{2} \mathrm{O} 0 \cdot 26, \mathrm{ZnCl}_{2} 0 \cdot 26$.

I The vitamin mixture was composed of the following ( $\mathrm{g} / \mathrm{kg}$ mixture): ascorbic acid $45 \cdot 0$, inositol $5 \cdot 0$, choline chloride $75 \cdot 0, p$-aminobenzoic acid 5.0 , nicotinamide 4.5 , menadione 0.0025 , pyridoxine hydrochloride $1 \cdot 0$, thiamin hydrochloride 1.0 , calcium pantothenate 3.0 , biotin 0.02 , folate 0.09 , cobalamin 0.00135 , riboflavin (omitted from the mixture used in the riboflavin-deficient diet) $1 \cdot 1$, cholecalciferol $0 \cdot 00125$, retinyl palmitate $0 \cdot 110$, DL- $\alpha$-tocopherol $2 \cdot 27$, dextrose to make $1 \mathrm{~kg}$.

\section{Expt 2}

Four groups of rats were used for the study: ad lib. (C), pair-fed (PF) and weight-matched (WM) controls and a riboflavin-deficient (RD) group. Three rats each from the C, PF and WM groups and five rats from the RD group were killed at intervals of 14, 21, 28, 35 and $49 \mathrm{~d}$ after being placed on their respective diets. Baseline estimation of liver ferritin-Fe concentration was made in five weanling rats at the start of the experiment (day 0). Rats were killed as described previously, blood was drawn from the heart into heparinized tubes and the livers were removed, blotted dry and weighed. Ferritin-Fe concentration was measured (Drysdale \& Ramsay, 1965) in homogenates $(100 \mathrm{~g} / \mathrm{l})$ after heating to $80^{\circ}$ followed by removal of heat-coagulated liver proteins by centrifugation. Ferritin was precipitated from the supernatant fraction by $50 \%$ saturation with ammonium sulphate. $\mathrm{Fe}$ in the precipitate was reacted with a chromogen $\left(2,2^{\prime}\right.$-bipyridine; Sigma Chemical Co., Poole, Dorset) and the pink colour developed was measured at $520 \mathrm{~nm}$ against a blank of $\mathrm{Fe}$-free distilled water. Fe present was calculated from a previously calibrated standard $\mathrm{Fe}$ curve.

\section{Measurement of riboflavin status}

Riboflavin status was monitored using the erythrocyte glutathione reductase (NAD(P)H) (EC 1.6.4.2, EGR) activation coefficient (EGRAC) test (Glatzle et al. 1970). EGR activity in $0.1 \mathrm{ml}$ haemolysate was measured in duplicate in $0.1 \mathrm{M}$-potassium phosphate buffer 


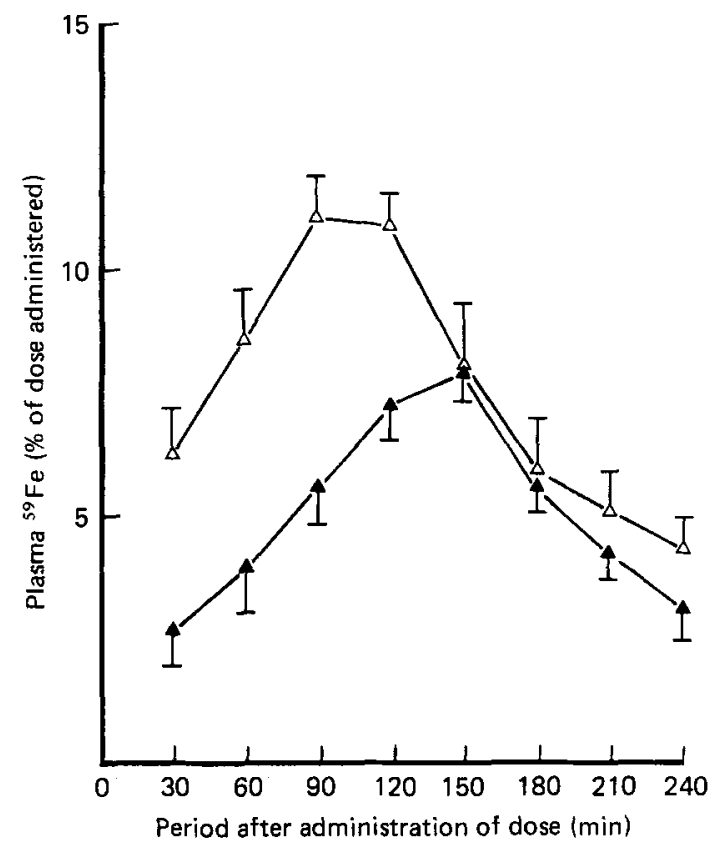

Fig. 1. Plasma ${ }^{59} \mathrm{Fe} 4 \mathrm{~h}$ after intragastric administration in riboflavin-deficient (RD) and weight-matched (WM) rats. Each point represents the mean percentage of a dose of ${ }^{58} \mathrm{Fe}$ measured in the plasma at each time-interval following intragastric administration in $\mathrm{RD}(\Delta)$ and $W M(\triangle)$ rats (standard errors represented by vertical bars, six rats/group).

(pH 7.4) containing 2.3 mM-dipotassium EDTA and 0.89 nM-oxidized glutathione (GSSG) with and without $8 \mu \mathrm{M}-\mathrm{FAD}$ in a reaction initiated by $80 \mu \mathrm{M}-\mathrm{NADPH}$ in a total volume of $3.6 \mathrm{ml}$. Cuvettes were incubated for 5-6 min before the addition of NADPH at $37^{\circ}$ and the decrease in absorbance over $10 \mathrm{~min}$ was recorded at $340 \mathrm{~nm}$ and $37^{\circ}$. The EGRAC is: change in absorbance over 10 min with FAD: change in absorbance over 10 min without FAD.

\section{RESULTS \\ Expt 1. Fe absorption}

Appearance of radio-Fe in plasma of RD and WM rats following intragastric administration of ${ }^{59} \mathrm{Fe}$ is shown in Fig. 1. Radio-Fe in the plasma of WM rats reached a peak of $11.4 \%$ of administered dose at 90 min after administration of ${ }^{59} \mathrm{Fe}$ into the stomach. By contrast, $\mathrm{RD}$ rats did not reach a peak until $150 \mathrm{~min}$ after administration, 60 min later than in WM rats and, even then, peak plasma radio-Fe $(7.8 \%)$ was only two-thirds that of WM rats. The corrected plots of actual plasma radio-Fe concentration, taking into consideration the proportion of radio-Fe removed from the plasma by different tissues during the study period, is shown in Fig. 2. In WM rats, the cumulative plot for ${ }^{59} \mathrm{Fe}$ in plasma showed that radio-Fe was still being absorbed at $4 \mathrm{~h}$, albeit at a considerably reduced rate which was significantly higher than the rate in RD rats. The total amount of radio-Fe in plasma of WM rats at $4 \mathrm{~h}(31 \cdot 1 \%)$ was significantly greater than that taken into the plasma of RD rats $(17.8 \%$ ) (Fig. $2 ; t$ test, $P<0.001$ ).

Fig. 3 shows the disappearance rate of plasma radio-Fe (plasma $t_{0.5}$ ) in C, WM and RD rats. The mean values for plasma $F e t_{0.5}$ in $C$ and WM rats were 61.1. (SE 2.08) and 60.7 (SE 3.4) min respectively, and these were not significantly different. The mean plasma $t_{0 \cdot 5}$ of RD rats was 80.6 (SE 4.3) min, and this was significantly slower than plasma $t_{0 \cdot 5}$ for $\mathrm{C}$ and WM rats $(P<0.025)$. 


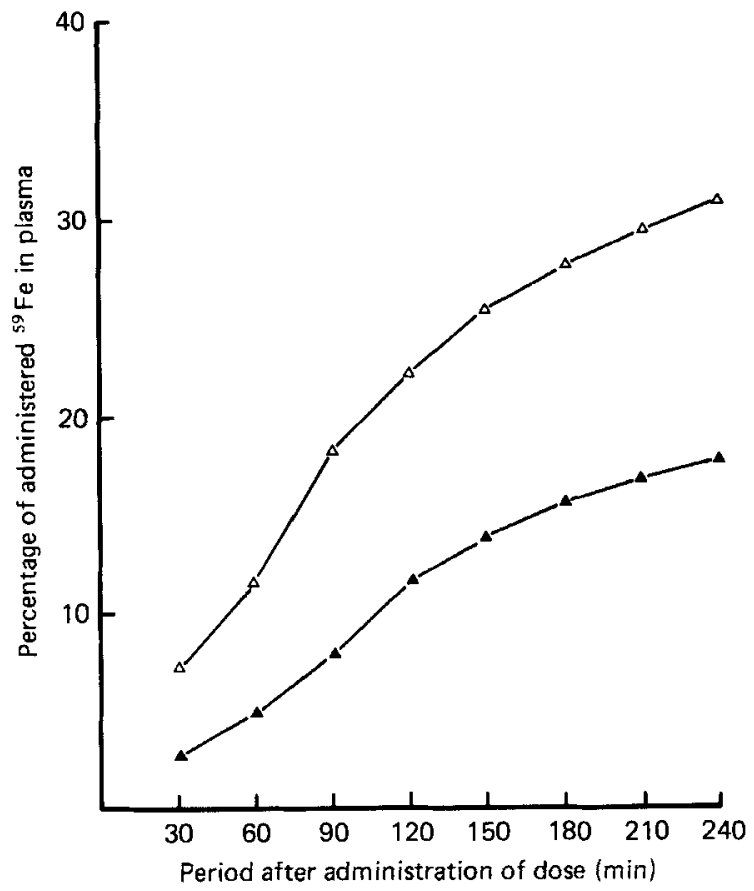

Fig. 2. Corrected plots of plasma ${ }^{59} \mathrm{Fe}$ in riboflavin-deficient $(\Delta)$ and weight-matched $(\triangle)$ rats $4 \mathrm{~h}$ after intragastric administration assuming no removal by tissues. Each point represents the corrected mean percentage of the administered dose of ${ }^{59} \mathrm{Fe}$ accumulating in the plasma at the end of each $30 \mathrm{~min}$ period assuming no removal of $\mathrm{Fe}$ by different tissues. Points are calculated from the values shown in Fig. 1.

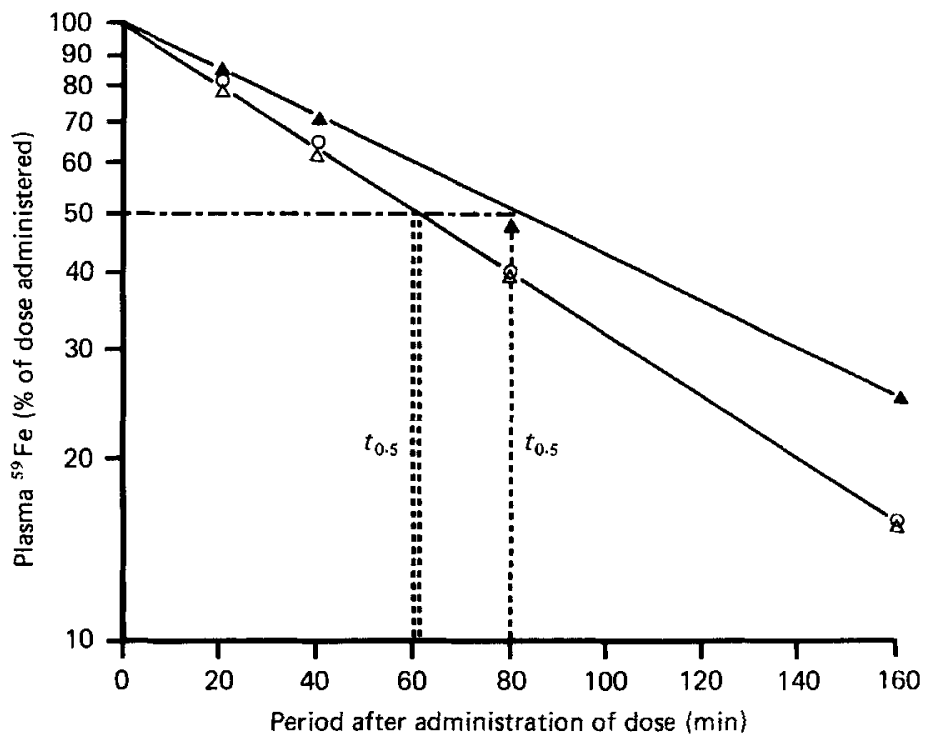

Fig. 3. Plasma iron disappearance rate (plasma half-life, $t_{0-5}$ ) following intravenous administration of ${ }^{59} \mathrm{Fe}$, showing the rate of disappearance of radio-Fe from the plasma in five ad lib.-fed control $(\mathrm{O} ; \mathrm{C})$, five weight-matched $(\triangle ; W M)$ and ten riboflavin-deficient rats $(\Delta ; R D)$. Plasma was collected from the tail vein at each time-point. (-__- ), Intersections with the disappearance curves when $50 \%$ of the administered dose of ${ }^{58} \mathrm{Fe}$ had been removed from the plasma. $(===)$, Time (min) when $50 \%$ of the administered dose had disappeared from the plasma of $\mathrm{C}$ and $\mathrm{WM}$ rats. (---), Time when $50 \%$ had disappeared from the plasma of the RD rats. 
Table $3 .{ }^{59} \mathrm{Fe}$ in stomach and intestine of weight-matched and riboflavin-deficient rats $(\%$ of dose administered) $4 \mathrm{~h}$ following intragastric administration of ${ }^{59} \mathrm{Fe}$

(Mean values and standard deviations for six rats/group)

\begin{tabular}{|c|c|c|c|c|c|c|c|c|}
\hline \multirow[b]{2}{*}{ Group* } & \multicolumn{2}{|c|}{ Stomach } & \multicolumn{2}{|c|}{ Duodenum } & \multicolumn{2}{|c|}{ Intestine } & \multicolumn{2}{|c|}{ Total } \\
\hline & Mean & SD & Mean & SD & Mean & SD & Mean & SD \\
\hline Weight-matched & 0.4 & $0 \cdot 16$ & $1 \cdot 6$ & 0.63 & 1.78 & 0.63 & $3 \cdot 78$ & $1 \cdot 25$ \\
\hline Riboflavin-deficient & $1 \cdot 55$ & $0 \cdot 4$ & $4 \cdot 1$ & $1 \cdot 5$ & $3 \cdot 46$ & $1 \cdot 56$ & $9 \cdot 11$ & 1.45 \\
\hline $\begin{array}{l}\text { Statistical significance of } \\
\text { difference: } P<\end{array}$ & 0.001 & & $0 \cdot 005$ & & 0.025 & & 0.001 & \\
\hline
\end{tabular}

* For details, see Tables 1 and 2.

Table 3 shows the percentage of radio-Fe retained in the tissues of the stomach and small intestine of $\mathrm{WM}$ and $\mathrm{RD}$ rats $4 \mathrm{~h}$ following intragastric administration of ${ }^{59} \mathrm{Fe}$. There remained little or no radioactivity in the stomach of WM rats, whereas about $1.5 \%$ of administered radio-Fe was recovered in the stomach of $\mathrm{RD}$ rats. Radioactivity recovered in the duodenum $(P<0.005)$ and the small intestine $(P<0.025)$ of RD rats was significantly greater than that in the duodenum and small intestine respectively of WM rats. In total, in the $\mathrm{RD}$ rats, almost $10 \%$ of administered radio-Fe was retained by the tissues of the stomach and small intestine compared with less than $4 \%$ in WM rats.

\section{Expt 2. Longitudinal changes in liver ferritin-Fe concentration}

Fig. 4 shows the concentrations of ferritin-Fe measured in the livers of C, PF, WM and $\mathrm{RD}$ rats over a 7 week period. The concentration of ferritin-Fe in the livers of weanling rats at the start of the experiment was $33 \mu \mathrm{g} / \mathrm{g}$ liver. At $14 \mathrm{~d}$ after the start of the experiment, an increase in ferritin-Fe concentration in the livers of all rats had occurred ( $t$ test; $P<0.025$ ), but there was no significant difference between the respective groups. At $21 \mathrm{~d}$ however, ferritin-Fe concentration in the livers of $\mathrm{RD}$ rats was significantly less than that in the livers of rats in the three control groups combined $(P<0.05)$ and remained lower until the termination of the experiment on day 49 . The lower concentration of liver ferritin-Fe in the RD rats at day 21 coincided with a significant increase in EGRAC (Table 4) even though no clinical sign of riboflavin deficiency was visible at this time.

\section{DISCUSSION}

In the present study, $\mathrm{Fe}$ absorption in RD rats was compared with that in WM rats. WM rats were used in preference to other control groups, e.g. ad lib. or pair-fed controls, because the growth rate in the latter rats is higher and consequently Fe requirements will also be higher than that in either $\mathrm{RD}$ rats or WM controls. Increased $\mathrm{Fe}$ requirement is accompanied by increased Fe absorption (Finch et al. 1978). In the WM and RD rats, however, the effects of such factors as blood volume and intestinal surface area which alter Fe absorption should be equalized.

The results of the present study suggest that Fe absorption was significantly impaired in RD rats by comparison with WM groups. This may be due in part to the fact that the tissues of the stomach and small intestine of $R D$ rats retained within them a significantly greater percentage of administered radio-Fe than that in the stomach and small intestine of WM rats. The duodenum of the rat has the highest absorptive capacity for Fe. This has 


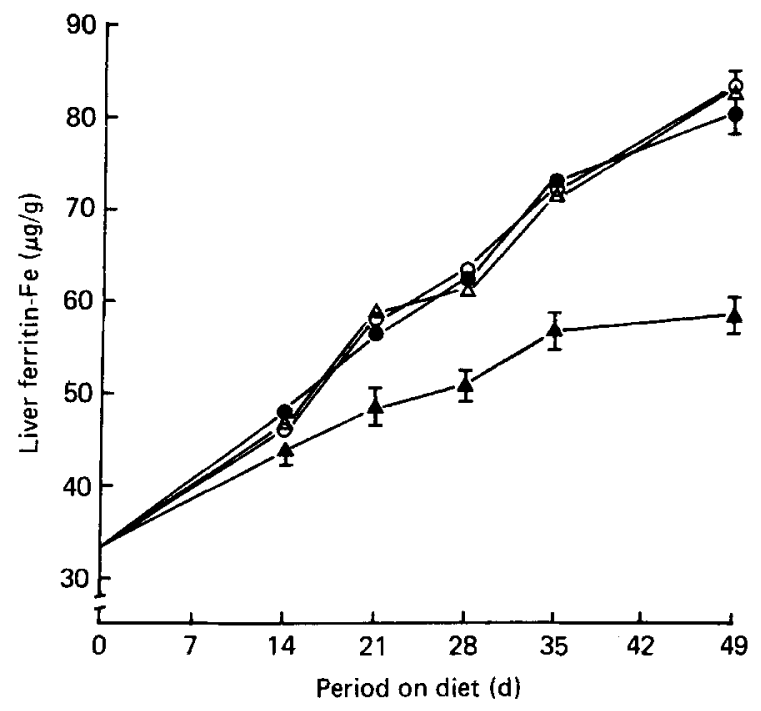

Fig. 4. Changes in liver ferritin-iron concentration with period (d) on the experimental diet. Points represent mean liver ferritin-Fe concentration measured at the intervals shown in three ad lib.-fed control $(\mathrm{O} ; \mathrm{C})$, three pair-fed $(\mathrm{O} ; \mathrm{PF})$, three weight-matched $(\triangle ; \mathrm{WM})$ and five riboflavin-deficient $(\triangle ; \mathrm{RD})$ rats, with their standard errors represented by vertical bars. For clarity, standard errors for the $C, P F$ and WM rats are not shown for days 14-35. They were, however, similar to those shown for other groups ranging from 0.6 to $2.3 \%$ of the means.

Table 4. Changes in riboflavin status (erythrocyte glutathione reductase $(N A D(P) H)(\mathrm{EC}$ 1.6.4.2) activation coefficient; $E G R A C$ ) with time in riboflavin-deficient and control rats

(Mean values and standard deviations, no. of rats in parentheses)

\begin{tabular}{|c|c|c|c|c|c|c|c|c|c|c|}
\hline \multirow{3}{*}{$\begin{array}{l}\text { Period on diet } \\
\text { (d)... } \\
\text { Group* }\end{array}$} & \multicolumn{10}{|c|}{ EGRAC } \\
\hline & \multicolumn{2}{|c|}{14} & \multicolumn{2}{|c|}{21} & \multicolumn{2}{|c|}{28} & \multicolumn{2}{|c|}{35} & \multicolumn{2}{|c|}{49} \\
\hline & Mean & SD & Mean & SD & Mean & SD & Mean & SD & Mean & SD \\
\hline $\begin{array}{l}\text { Ad lib.-fed } \\
\text { control }\end{array}$ & 1.25 & $0 \cdot 16$ & 1.08 & 0.05 & $1 \cdot 28$ & 0.19 & $1 \cdot 25$ & 0.05 & 1.23 & 0.03 \\
\hline Pair-fed & 1.28 & $0 \cdot 10$ & $1 \cdot 13$ & 0.04 & $1 \cdot 25$ & 0.23 & 1.44 & 0.22 & $1 \cdot 33$ & 0.08 \\
\hline Weight-matched & 1.24 & $0 \cdot 13$ & 1.26 & $0 \cdot 3$ & 1.42 & 0.03 & $1 \cdot 46$ & 0.22 & $1 \cdot 41$ & 0.02 \\
\hline $\begin{array}{l}\text { Riboflavin- } \\
\text { deficient }\end{array}$ & 1.46 & 0.23 & 1.81 & 0.18 & 1.88 & 0.19 & $2 \cdot 31$ & 0.55 & 2.66 & $0 \cdot 27$ \\
\hline
\end{tabular}

* For details, see Tables 1 and 2.

been demonstrated both with isolated duodenal segments (Brown \& Justus, 1958; Dowdle et al. 1960; Manis \& Schacter, 1962; Jacobs et al. 1966; Howard \& Jacobs, 1972) and in the intact animal (Duthie, 1964; Wheby, 1970). Wheby et al. (1964) reported that some Fe can also be absorbed through the stomach. Accumulation of a significantly higher amount of $\mathrm{Fe}$ in the tissues of the stomach and small intestine of RD rats than in WM rats would therefore diminish the amount of Fe that could be transferred into the blood, thereby decreasing total Fe absorption. A variable proportion of the Fe held within the tissues of 
the stomach and small intestine of RD rats would be lost into the gut when mucosal cells exfoliated.

The accumulation of $\mathrm{Fe}$ in the gut mucosa of $\mathrm{RD}$ rats may be the result of a decrease in the activity of the enzyme, NADH-FMN oxidoreductase. It has been proposed that this enzyme is responsible for the mobilization of Fe from ferritin (Osaki \& Sirivech, 1971). The enzyme requires FMN, the amount of which is proportionately lower in riboflavin deficiency than that of FAD (Rivlin, 1970). The preferential reduction in FMN concentration may explain the decrease in activity of NADH-FMN oxidoreductase in the duodenum of RD rats which was reported by Sirivech et al. (1977). A significant decrease in the activity of this enzyme in the duodenum of RD rats may explain why more radioactivity remained in the gut of the RD rats than in the WM rats in the present study, and why the increase in plasma $\mathrm{Fe}$ following the intragastric dose of ${ }^{59} \mathrm{Fe}$ was both delayed and reduced in the $\mathrm{RD}$ rats.

Storage $\mathrm{Fe}$ in the livers of the RD rats was found to be significantly lower than that in livers of rats in the $\mathrm{C}, \mathrm{PF}$ and WM groups from 3 weeks onwards when the mean EGRAC was 1.81 (SD $0 \cdot 18$ ), i.e. when biochemical riboflavin deficiency was well established.

It has been established that there is a large store of $\mathrm{Fe}$ in the rat at birth (McCance \& Widdowson, 1951) and that most of this Fe is located as ferritin in the liver (Cox \& Schlicker, 1967; Kaufman \& Wyllie, 1970). This large store of Fe is, however, rapidly depleted during the sucking period because of the rapid growth of body mass (McCance \& Widdowson, 1951; Mazur \& Carleton, 1965; Leslie \& Kaldor, 1971). Fe accumulation in storage compartments resumes after weaning (Linder et al. 1972). In the present study, rats in the $\mathrm{C}, \mathrm{PF}$ and WM groups progressively accumulated $\mathrm{Fe}$ in their livers throughout the experimental period; by contrast, although $\mathrm{RD}$ rats accumulated some Fe in their livers, the mean amount was significantly less than that in livers of rats in the three other groups. Zaman \& Verwilghen (1977) demonstrated, however, that there was no defect in the incorporation of $\mathrm{Fe}$ into liver ferritin in $\mathrm{RD}$ rats for ${ }^{59} \mathrm{Fe}$ given intravenously as $\mathrm{Fe}$ was taken up as effectively by RD rats as by the control rats. The failure of the RD rats in the experiments reported here to accumulate as much $\mathrm{Fe}$ in their livers as in any of the control rats must therefore be the result of impaired Fe absorption. However, it is not generally believed that ferritin plays an active role in the transport of Fe across the mucosal cell, thus an impairment in $\mathrm{Fe}$ absorption could not be anticipated from the observation of Sirivech et al. (1977). The results suggest, therefore, that ferritin is actively involved in the uptake and transport of Fe across the mucosal cell in the RD rat. Fig. 2 shows that Fe can accumulate less rapidly in the RD rat both during the initial uptake and in the latter stages than in the WM rats. This may indicate that ferritin-independent $\mathrm{Fe}$ absorption may be depressed initially, and the RD rat is forced to draw on the ferritin reserves in the mucosal cell to a greater extent than in the WM rats. In these circumstances the reduced activity of NADH-FMN oxidoreductase demonstrated by Sirivech et al. (1977) may depress the net amount of $\mathrm{Fe}$ absorbed by impairing its release from ferritin. However, in our experience the amount absorbed is able to maintain a normal haemopoietic system in the rat but is insufficient for normal storage of liver ferritin to occur.

D.A.A. was in receipt of financial support from the University of Ife, Nigeria and of an ORS Award from the Committee of Vice-Chancellors and Principals. D. I. T. is supported by the Department of Health and Social Security. 


\section{REFERENCES}

Alfrey, C. P. \& Lane, M. (1970). Seminars in Haematology 7, 49-54.

Bothwell, T. H., Mallet, B., Oliver, R. \& Smith, M. D. (1955). British Journal of Haematology 1, $352-357$.

Brown, E. B. Jr \& Justus, B. W. (1958). American Journal of Physiology 194, 319-326.

Cox, D. H. \& Schlicker, S. A. (1967). Biochemical Medicine 1, 230-239.

Dowdle, E. B., Schacter, D. \& Schenker, H. (1960). American Journal of Physiology 198, 609-613.

Drysdale, J. W. \& Ramsay, W. N. M. (1965). Biochemical Journal 95, 282-288.

Duthie, H. L. (1964). British Journal of Haematology 10, 59-68.

Finch, C. A., Ragan, H. A., Dyer, I. A. \& Cook, J. D. (1978). Proceedings of the Society of Experimental Biology and Medicine 159, 335-338.

Glatzle, D., Körner, W. F., Christeller, S. \& Wiss, O. (1970). International Journal of Vitamin and Nutrition Research 40, 166-183.

Hoppel, R. L. \& Tandler, B. (1975). Journal of Nutrition 105, 562-570.

Howard, J. \& Jacobs, A. (1972). British Journal of Haematology 23, 595-603.

Jacobs, P., Bothwell, T. H. \& Charlton, R. W. (1966). American Journal of Physiology 210, $694-700$.

Jamdar, S. C., Udupa, K. B. \& Chatterji, A. (1968), Journal of Vitaminology 14, 219-222.

Kaufman, N. \& Wyllie, J. C. (1970). British Journal of Haematology 19, 515-521.

Lane, M., Alfrey, C. P. Jr, Mengel, D. E., Doherty, M. A. \& Doherty, J. (1964). Journal of Clinical Investigation 43, 357-373.

Leslie, A. J. \& Kaldor, I. (1971). American Journal of Physiology 220, 1000-1004.

Linder, M. C., Moor, J. R., Scott, L. E. \& Munro, H. N. (1972). Biochemical Journal 129, 455-462.

Linder, M. C., Moor, J. R., Scott, L. E. \& Munro, H. N. (1973). Biochimica et Biophysica Acta 297, 70-80.

McCance, R. A. \& Widdowson, E. M. (1951). Journal of Physiology 112, 450-458.

Manis, J. G. \& Schacter, D. (1962). American Journal of Physiology 203, 81-86.

Mazur, A. \& Carlton, A. (1965). Blood 26, 317-322.

Mookerjea, S. \& Hawkins, W. W. (1960). British Journal of Nutrition 14, 239-246.

Osaki, S. \& Sirivech, S. (1971). Federation Proceedings 30, 1292 Abstr.

Rivlin, R. S. (1970). New England Journal of Medicine 283, 463-472.

Shiano-Chun, T., Becvar, J. E. \& Hastings, J. W. (1979). Archives of Biochemistry and Biophysics 193, $110-116$.

Sirivech, S., Driskell, J. \& Frieden, E. (1977). Journal of Nutrition 107, 739-745.

Van Wyke, C. P., Linder-Horowitz, M. \& Munro, H. N. (1971). Journal of Biological Chemistry 246, $1025-1031$.

Wheby, M. S. (1970). Scandinavian Journal of Haematology 7, 56-62.

Wheby, M. S., Jones, L. G. \& Crosby, W. H. (1964). Journal of Clinical Investigation 43, 1433-1442.

Zaman, Z. \& Verwilghen, R. L. (1977). Biochemical Society Transactions 5, 306-308. 